\title{
Class-Switching of B Lymphocytes by DNA and Cell Immunization for Stereospecific Monoclonal Antibodies against Native GPCR
}

\author{
Yushi Isozaki *, Kanta Tsumoto (D) and Masahiro Tomita *
}

Division of Chemistry for Materials, Graduate School of Engineering, Mie University, 1577 Kurimamachiya-cho, Tsu 514-8507, Japan; tsumoto@chem.mie-u.ac.jp

* Correspondence: yushi.isozaki@gmail.com (Y.I.); tomita@chem.mie-u.ac.jp (M.T.); Tel.: +81-59-231-9429 (M.T.)

Citation: Isozaki, Y.; Tsumoto, K.; Tomita, M. Class-Switching of B Lymphocytes by DNA and Cell Immunization for Stereospecific Monoclonal Antibodies against Native GPCR. Immuno 2021, 1 , 432-441. https://doi.org/10.3390/ immuno1040031

Academic Editor: Ulrich Sack

Received: 30 September 2021 Accepted: 8 November 2021 Published: 12 November 2021

Publisher's Note: MDPI stays neutral with regard to jurisdictional claims in published maps and institutional affiliations.

Copyright: (c) 2021 by the authors. Licensee MDPI, Basel, Switzerland. This article is an open access article distributed under the terms and conditions of the Creative Commons Attribution (CC BY) license (https:// creativecommons.org/licenses/by/ $4.0 /)$.

\begin{abstract}
To develop efficient applications of monoclonal antibodies for therapeutic purposes, stereospecific recognition of the target antigens is needed. DNA immunization is one of the best methods for sensitizing B lymphocytes that can produce conformation-specific antibodies. Here we verified the class-switching of monoclonal antibodies by DNA immunization followed by cell immunization for the generation of stereospecific monoclonal antibodies against native $G$ protein-coupled receptor (GPCR) using the optimized stereospecific targeting (SST) technique. This technology facilitates the efficient selection of sensitized B lymphocytes through specific interaction with the intact antigen via B-cell receptors (BCRs). We demonstrate that multiple DNA immunizations followed by a single cell immunization in combination with a longer sensitization period (three to four months) are an appropriate sensitizing strategy for the generation of IgG-type stereospecific monoclonal antibodies by class-switching, and the characteristics of antibody production could be transferred to hybridoma cells provided by the optimized SST technique.
\end{abstract}

Keywords: B-cell receptor (BCR); class-switching; DNA immunization; G protein-coupled receptor (GPCR); native antigen; stereospecific monoclonal antibody

\section{Introduction}

DNA and mRNA vaccines are expected to become a state-of-the-art vaccination for the prevention of diseases [1]. To acquire immunity, while most genes are introduced into muscle cells and keratinocytes, some are introduced into dendritic cells, where they are expressed [2]. The transfected cells are phagocytosed by antigen-presenting cells (APCs) and presented to helper $\mathrm{T}$ lymphocytes to initiate a humoral immunity [2]. Vaccination with DNA and mRNA genes may involve a common process for eliciting an immune response by expressing native antigens in vivo [3,4]. However, it remains unclear how the immune response works against intact antigens, which possess a native conformation with respect to their polypeptide chains.

Monoclonal antibodies have been known to be critically important in a wide range of scientific fields because of their high specificity and affinity. Especially, they have been attracting attention as a new therapeutic medicine in recent years [5]. For this purpose, an IgG isotype of monoclonal antibodies is preferable [6], as these antibodies are stable with higher affinity and thus are suitable for the formulation of antibody-drug conjugates [7].

We previously reported a novel technology termed optimized stereospecific targeting (SST) [8-10], which consists of three important steps: (1) DNA immunization; (2) B-cell selection by antigen-expressing myeloma cells; and (3) selective fusion of B cell and myeloma cell complexes, to generate hybridoma cells that secrete stereospecific monoclonal antibodies. The optimized SST technique features the selective production of conformation-specific monoclonal antibodies against membranous proteins such as receptors with high efficiency $[9,10]$. 
Generally, antibodies class-switch to improve the effector effect and increase their ability to eliminate pathogens [11,12]. Class-switching to IgG to gain higher affinity occurs in pre-immunized $B$ cells at variable exon regions in the heavy and light chains of the antibody via $\mathrm{V}$ (D) J recombination. B cells undergo somatic hypermutation and class switch recombination (CSR) of the immunoglobulin gene in the germinal center [13]. Somatic hypermutations cause many point mutations in $\mathrm{V}$ exons, producing high-affinity antibodies to specific antigens in a process called affinity maturation. CSR replaces the Ig heavy chain constant region $(\mathrm{CH})$ gene from $\mathrm{C} \mu$ to other $\mathrm{CH}$ genes and switches the Ig isotype from IgM to either IgG, IgE, or IgA [11-13]. B cells undergo an Ig class switch in vivo after immunization or infection [11-14]. This implies that combination of the SST technology and the class-switch in immunization could increase the possibility for efficient acquisition of hybridoma cells producing stereospecific monoclonal IgG antibodies against target antigens.

In this study, we verified the class-switching of stereospecific monoclonal antibodies to IgG against intact human corticotropin-releasing hormone receptor 1 (huCRHR1) [15], which is a member of the GPCRs, by a combination of multiple DNA immunizations and cell-based immunization based on the optimized SST technique.

\section{Materials and Methods}

\subsection{Materials}

Goat anti-mouse $\operatorname{IgG}(\mathrm{H}+\mathrm{L})$ antibody conjugated with horseradish peroxidase (HRP) (catalog No.: SA00001-1) was purchased from BioSource International (Camarillo, CA, USA). Affinipure goat anti-mouse IgG (Fc $\gamma$ ) antibody (catalog No.: 115-005-008) and goat antimouse IgM ( $\mu$ chain specific) antibody (catalog No.: 115-005-020) were purchased from Jackson ImmunoResearch Laboratories, Inc. (West Grove, PA, USA).

\subsection{Mice}

BALB/cA Jcl female mice were purchased from CLEA Japan (Tokyo, Japan) and used for immunization at the age of 5 weeks. All experiments were approved and conducted according to the Mie University guidelines for the care and treatment of experimental animals.

\subsection{Cell Culture}

PAI murine myeloma cells [16] were grown in complete RPMI 1640 medium at $37^{\circ} \mathrm{C}$ in a humidified atmosphere containing $5 \% \mathrm{CO}_{2}$. Complete RPMI 1640 medium was prepared by supplementation with $10 \%$ fetal calf serum (FCS), $2 \mathrm{mM}$ L-glutamine (Nissui Pharmaceutical Corporation, Tokyo, Japan), and $100 \mu \mathrm{g} / \mathrm{mL}$ kanamycin sulfate (Meiji Seika Corporation, Tokyo, Japan).

Chinese hamster ovary $(\mathrm{CHO})-\mathrm{K} 1$ cells were grown in complete E-RDF medium (Kyokuto Pharmaceutical Industrial Corporation, Tokyo, Japan) supplemented with 10\% FCS at $37^{\circ} \mathrm{C}$ in a humidified atmosphere with $5 \% \mathrm{CO}_{2}$.

\subsection{Recombinant Plasmid Vectors}

pBCMGS-huCRHR1 recombinant plasmid vector was prepared by inserting huCRHR1 gene (cDNA Resource Center, Bloomsburg University, Bloomsburg, PA, USA) from pcDNA3.1-huCRHR1 using XhoI and NotI sites. pBCMGS-huCRHR1-green fluorescent protein (GFP) recombinant plasmid vector was prepared by inserting huCRHR1-GFP genes from pcDNA3.1-huCRHR1-pTagGFP2-N using XhoI and NotI sites.

\subsection{Recombinant Cells}

Myeloma cells $\left(5.0 \times 10^{4}\right.$ cells $\left./ 500 \mu \mathrm{L}\right)$ and CHO-K1 cells $\left(5.0 \times 10^{4}\right.$ cells/500 $\left.\mu \mathrm{L}\right)$ were cultured in a 24-well plate under a humidified 5\%: 95\% $\mathrm{CO}_{2} /$ air gas mixture at $37^{\circ} \mathrm{C}$ for one day. Transfection by pBCMGS-huCRHR1-GFP was performed by using an HVJ Envelope VECTOR KIT “GenomONE-Neo” (Ishihara Sangyo Kaisha, Osaka, Japan), ac- 
cording to the manufacturer's instructions. Temporary and stably expressed huCRHR1 was confirmed by the expression of GFP which was linked to the C terminus of huCRHR1.

To establish a stable form of recombinant myeloma cells, temporary transfected myeloma cells were further selected by incubation in complete RPMI 1640 medium in the presence of $500 \mu \mathrm{g} / \mathrm{mL}$ of G418 for 10 to 14 days. Stable recombinant CHO-K1 cells were obtained as described above, except that complete E-RDF medium and $1300 \mu \mathrm{g} / \mathrm{mL}$ of G418 were used.

\subsection{Immunization}

Recombinant plasmid DNA pBCMGS-huCRHR1 was injected into the thigh muscle of legs for DNA immunization at 3-week intervals after BALB/cA Jcl mice were anesthetized. Fifty microliters of recombinant plasmid DNA $(1.0 \mu \mathrm{g} / \mu \mathrm{L})$ in a leg were used for the first immunization. Thirty microliters of recombinant plasmid DNA $(1.0 \mu \mathrm{g} / \mu \mathrm{L})$ in a leg were used for additional immunizations. To effectively transfer recombinant plasmid vectors into cells, an electric field of $200 \mathrm{~V} / \mathrm{cm}$ was applied to the site of injection for $20 \mathrm{~ms}$, and repeated four times at 1-s intervals, by use of a 2-needle array separated by $5 \mathrm{~mm}$. Human CRHR1-expressing CHO-K1 cells (approx. $1 \times 10^{7}$ cells) suspended in $0.5 \mathrm{~mL}$ of phosphatebuffered saline ( $\mathrm{pH}=7.2)(\mathrm{PBS})$ were intraperitoneally injected as a final immunization at three to five days before fusion. Three mice per group were sensitized by DNA and cell immunization at one time. One of the sensitized mice was used for each experiment.

\subsection{Optimized Stereospecific Targeting (SST) Technique}

The optimized SST technique was used to generate hybridoma cells secreting the target conformation-specific monoclonal antibodies, as previously reported [8-10]. In brief, the spleen was aseptically removed from a mouse after DNA immunization and cell immunization. A cell suspension containing sensitized B lymphocytes was prepared from the spleen. Target-sensitized B lymphocytes were selected by huCRHR1-expressing myeloma cells via BCRs by incubating for $30 \mathrm{~min}$ at $4{ }^{\circ} \mathrm{C}$ after slowly spinning down the cell suspension, followed by gentle rotation for another $30 \mathrm{~min}$ at $4^{\circ} \mathrm{C}$. Finally, B cell-myeloma cell complexes were selectively fused by electrical pulses with a square wave at $2.0-3.0 \mathrm{kV} / \mathrm{cm}$ for a duration of $10 \mu \mathrm{s}$, repeated four times at 1-s intervals to produce hybridoma cells secreting the desired monoclonal antibodies. Single-cell suspension in separate wells during fusion with myeloma cells was not used. Hybridoma cells were selected in complete RPMI 1640 medium in the presence of HAT and HT medium.

\subsection{Cell-Based Enzyme-Linked Immunosorbent Assay (Cell-ELISA)}

Human CRHR1-expressing CHO-K1 cells $\left(2.0-3.5 \times 10^{4}\right.$ cells $\left./ 200-350 \mu \mathrm{L}\right)$ were incubated in a 96-well culture plate in complete E-RDF medium at $37^{\circ} \mathrm{C}$ in a humidified atmosphere containing $5 \% \mathrm{CO}_{2}$ for one to two days. Each well was washed with PBS, and hybridoma supernatant or 1/50-1/1600-fold diluted mouse serum after DNA and cell immunization was added as a primary antibody with incubation for $2 \mathrm{~h}$ at $4{ }^{\circ} \mathrm{C}$. After washing with PBS, 1/10,000-diluted goat anti-mouse $\operatorname{IgG}(\mathrm{H}+\mathrm{L})$ antibody conjugated with HRP was added as a secondary antibody, and the mixture was incubated for $1 \mathrm{~h}$ at $4{ }^{\circ} \mathrm{C}$. Each well was washed at least five times with PBS, and the absorbance was measured at $490 \mathrm{~nm}$ using $o$-phenylenediamine as a substrate [9,10]. $\Delta O D$ values at $490 \mathrm{~nm}$ (OD490 nm-blank OD490 nm) denote specific binding of stereospecific monoclonal antibodies to the intact antigen.

\subsection{Isotype of Antibodies}

Fifty microliters of anti-mouse $\operatorname{IgM}$ ( $\mu$ chain specific) antibody $(10 \mu \mathrm{g} / \mathrm{mL}$ ) and of anti-mouse IgG (Fc $\gamma)$ antibody $(10 \mu \mathrm{g} / \mathrm{mL})$ were adsorbed on a $96-$ well plate overnight at $4{ }^{\circ} \mathrm{C}$. Each well was blocked with $1 \%$ gelatin in PBS for more than $2 \mathrm{~h}$ at $37^{\circ} \mathrm{C}$, and washed three times with PBST (PBS containing $0.05 \%$ Triton-X). Hybridoma supernatant or 1/2000-1/1,000,000—fold diluted mouse serum after DNA and cell immunization was 
added as a primary antibody and incubated for $1 \mathrm{~h}$ at $37^{\circ} \mathrm{C}$. After washing with PBST, 1/10,000-diluted goat anti-mouse $\operatorname{IgG}(\mathrm{H}+\mathrm{L})$ antibody conjugated with HRP was added as a secondary antibody, and incubated for $1 \mathrm{~h}$ at $37^{\circ} \mathrm{C}$. After washing at least five times with PBST, the absorbance was measured at $490 \mathrm{~nm}$ by using o-phenylenediamine as a substrate as described above.

\section{Results and Discussion}

\subsection{DNA and Cell Immunization for Optimized Stereospecific Targeting (SST)}

Based on the optimized SST technique, B lymphocytes sensitized by a combination of DNA immunization followed by cell-based immunization were selected by antigenexpressing myeloma cells through B-cell receptor (BCR). B cell and myeloma cell complexes were then selectively fused by electrical pulses to produce hybridoma cells that can secrete conformation-specific monoclonal antibodies (Figure 1). The critical points of the technique are DNA immunization, B-cell selection by antigen-expressing myeloma cells, and selective fusion of B cell and myeloma cell complexes [8-10]. DNA immunization must be a privileged method to selectively sensitize the target $B$ lymphocytes that produce antibodies recognizing the native structures of the target antigen. The intact antigens on the surface of myeloma cells are essential, because these recombinant cells can preferentially select $B$ lymphocytes that recognize the native target antigen via $B C R s$ to increase the possibility that $B$ cells producing stereospecific antibodies against the target antigen can be transformed into hybridoma cells. In fact, attached B cell and myeloma cell complexes are predominantly selected to be fused by an electric field by avoiding undesired fusion among other unattached cells [17].

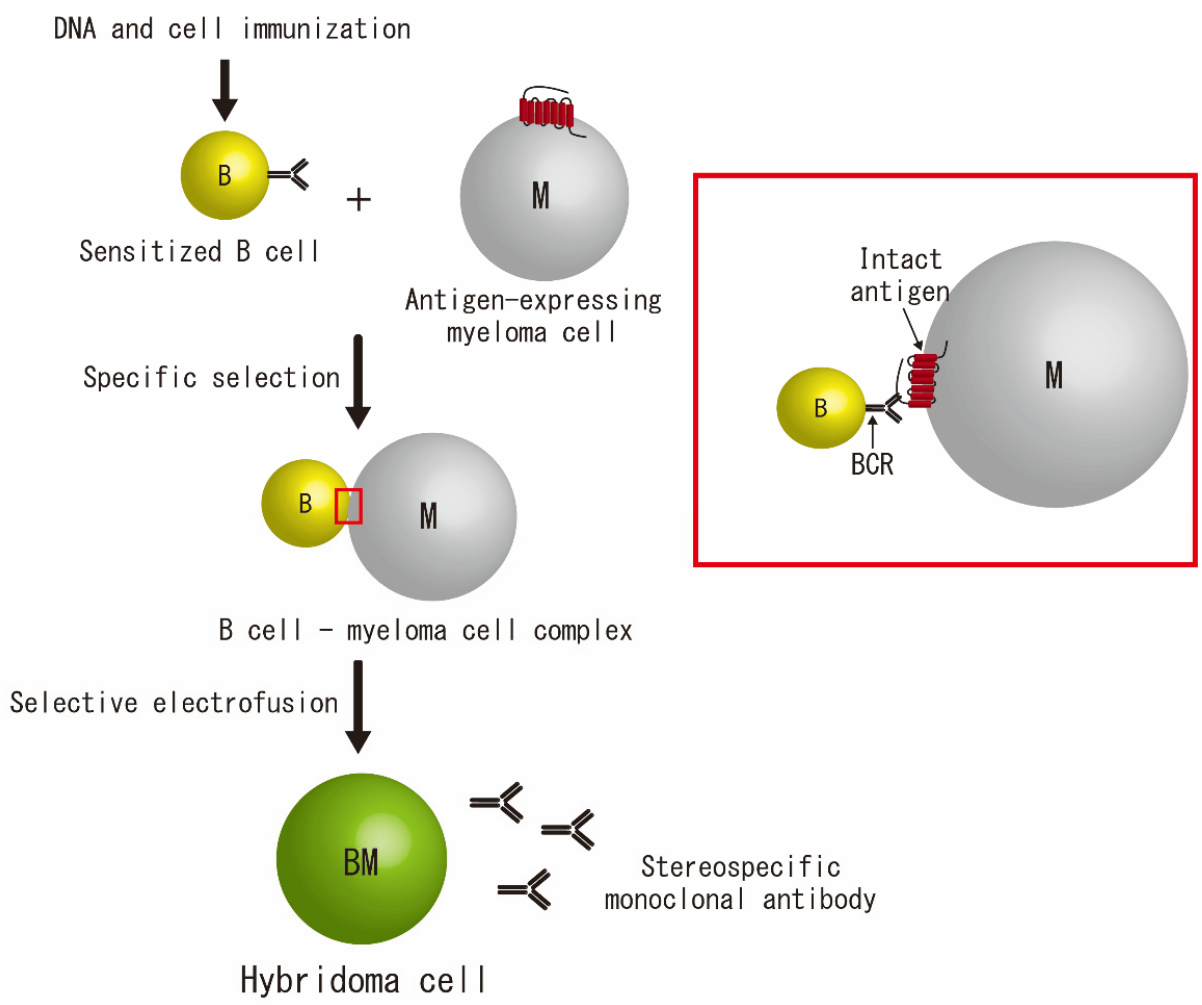

Figure 1. Optimized stereospecific targeting (SST) technique. The optimized stereospecific targeting (SST) technique consists of two critical steps after both DNA and cell immunization. The first step is that sensitized B lymphocytes are selected by antigen-expressing myeloma cells through BCRs. B cell-myeloma cell complexes are then selectively fused by an electric field to produce hybridoma cells secreting stereospecific monoclonal antibodies in the second step.

We adopted five protocols for immunization, termed Fusion I to Fusion V, which differ in the number of DNA immunizations, fusion days, and total weeks for sensitization, to 
selectively generate stereospecific monoclonal antibodies against huCRHR1, as shown in Table 1. In Fusion I, more IgM-type antibodies were produced in serum by three DNA immunizations and one cell-based immunization (Figure 2A). In contrast, in Fusion V, a higher level of IgG-type antibody production was recognized in serum after sensitization by four DNA immunizations and one cell immunization (Figure 2B). Notably, the affinity of antibodies for huCRHR1 was remarkably enhanced in Fusion V (Figure 2C). These results demonstrate that class-switching of IgM to IgG could provide the affinity maturation of stereospecific antibodies to the target antigen, even when DNA and cell immunization are used to sensitize B lymphocytes.

A

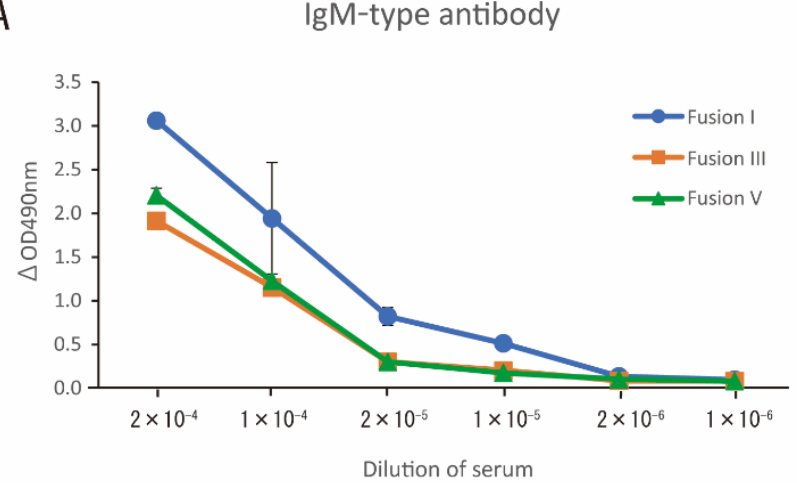

B
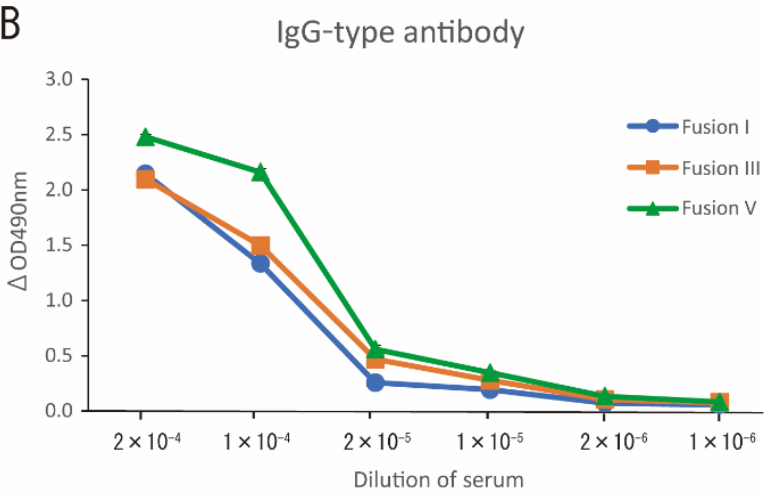

C

Cell-ELISA

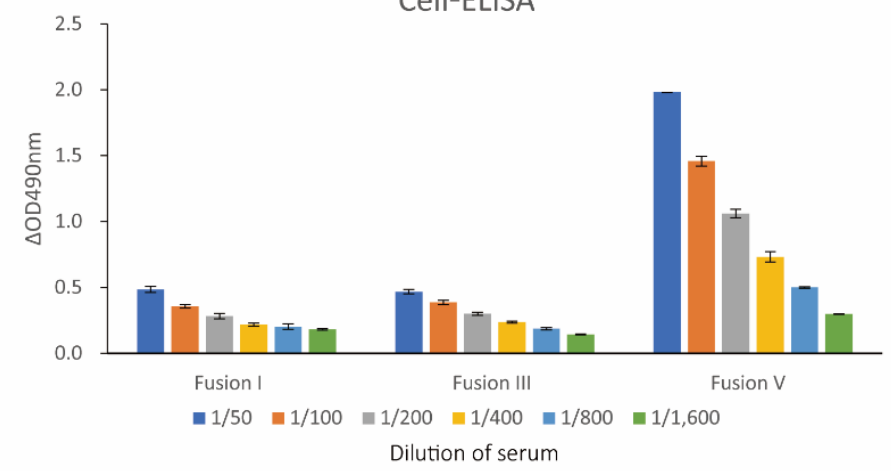

Figure 2. Determination of the isotype and titer of antibodies after DNA and cell immunization. (A) IgM-type and (B) IgG-type antibodies in serum were determined by the ELISA method after mice were sensitized by DNA and cell immunization according to the protocols in Fusions I, III, and V. (C) Specific binding of antibodies in serum to intact huCRHR1 on CHO cells was quantified by the Cell-ELISA method after DNA and cell immunization based on the sensitizing methods of Fusions I, III, and V. Results are shown as the mean \pm standard deviation $(n=2)$. Some error bars are hidden behind each symbol due to the small standard deviation values.

DNA immunization has been used with a variety of proteins, including transmembrane proteins [18-20]. It has been reported that immunization is performed four times at intervals of three to six weeks using a gene gun [21] and three times at 3-week intervals by intramuscular injection [18]. Electroporation can also be used under a wide range of conditions $[20,22,23]$. In the present study, we performed DNA immunization three or four times at 3-week intervals. In addition, target antigen-expressing $\mathrm{CHO}$ cells were used in a final immunization to provide a stronger immune response [24]. 


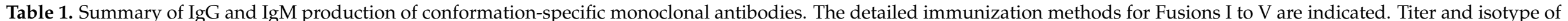

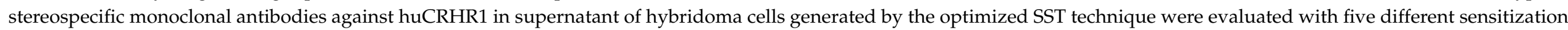
protocols in Fusions I to V.

\begin{tabular}{|c|c|c|c|c|c|c|c|c|c|c|}
\hline \multirow{2}{*}{$\begin{array}{l}\text { Immunization } \\
\text { Method }\end{array}$} & \multirow{2}{*}{$\begin{array}{l}\text { Number of DNA } \\
\text { Immunization } \\
\text { (Total Weeks for } \\
\text { Immunization) a) }^{\text {a }}\end{array}$} & \multirow{2}{*}{ Fusion Day $^{b}$} & \multirow{2}{*}{$\begin{array}{c}\text { Number of } \\
\text { Wells }\end{array}$} & \multirow{2}{*}{$\begin{array}{l}\text { Hybridoma } \\
\text { Positive Wells }\end{array}$} & \multirow{2}{*}{$\begin{array}{c}\text { Cell-ELISA } \\
\text { Positive Wells }{ }^{c}\end{array}$} & \multirow{2}{*}{$\begin{array}{l}\text { Isotype-Determined } \\
\text { Wells (A) }\end{array}$} & \multicolumn{2}{|c|}{ Isotype } & \multirow{2}{*}{$\begin{array}{c}\text { Rate of IgG } \\
\text { Production } \\
\text { (B)/(A) } \times 100(\%)\end{array}$} & \multirow{2}{*}{$\begin{array}{c}\text { Rate of IgM } \\
\text { Production } \\
\text { (C)/(A) } \times 100(\%)\end{array}$} \\
\hline & & & & & & & 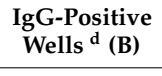 & $\begin{array}{l}\text { IgM-Positive } \\
\text { Wells e (C) }\end{array}$ & & \\
\hline Fusion I & $3(9)$ & 3 & 192 & 107 & 14 & 14 & 0 & 13 & 0 & 92.9 \\
\hline Fusion II & $3(8)$ & 5 & 288 & 29 & 8 & 8 & 4 & 8 & 50.0 & 100.0 \\
\hline Fusion III & $3(11)$ & 5 & 288 & 25 & 9 & 5 & 4 & 5 & 80.0 & 100.0 \\
\hline Fusion IV & 4 (12) & 5 & 192 & 78 & 22 & 13 & 13 & 6 & 100.0 & 46.2 \\
\hline Fusion V & $4(15)$ & 5 & 192 & 22 & 3 & 3 & 3 & 0 & 100.0 & 0 \\
\hline
\end{tabular}

$\mathrm{a}:$ Including cell immunization; $\mathrm{b}:$ After the final immunization; $\mathrm{c}: \Delta \mathrm{OD}_{490 \mathrm{~nm}}>0.1 ; \mathrm{d}: \Delta \mathrm{OD}_{490 \mathrm{~nm}}>0.5 ; \mathrm{e}: \Delta \mathrm{OD}_{490 \mathrm{~nm}}>0.5$ 


\subsection{Effect of the Number of DNA Immunizations and the Sensitization Period on Class-Switching}

To further evaluate the five protocols, the class-switching process from IgM to IgG was investigated in detail. For this purpose, we used mixtures of hybridoma cells obtained by fusion of each of sensitized B lymphocytes with a single myeloma cell using the optimized SST technique, resulting in producing polyclonal antibodies consisting of various kinds of monoclonal antibodies. It is noted that the previous microscopic observation suggested that a pair of a B-cell and a myeloma cell can often be selected to fuse with each other when applying the electrical pulse with our method [9]. The immunization conditions for Fusions I to III involve three DNA immunizations followed by cell-based immunization as a final sensitization. The total period for these immunizations was two to three months. Most stereospecific monoclonal antibodies produced by hybridoma cells that were positive by Cell-ELISA conferred the IgM-type isotype; of course, a small number of hybridoma cells in the same wells concomitantly secreted IgG-type antibodies against huCRHR1 prior to further limiting dilution (Figure 3A-C, Table 1).

In contrast, the ratio of IgG-type stereospecific monoclonal antibodies to IgM-type was apparently increased in Fusion IV and V by four DNA immunizations and one cell immunization with a relatively longer sensitization period of more than three months (Figure 3D,E, Table 1). The class-switching of conformation-specific monoclonal antibodies could be controlled by the number of DNA immunizations and the sensitization period, and the characteristics of antibody production could be transferred to the hybridoma cells provided by the optimized SST technique. Here, $\triangle$ OD values at $490 \mathrm{~nm}$ (OD490 nm-blank OD490 nm) of more than 0.1 were regarded as Cell-ELISA positive, where OD490nm values were at least 3.5-times higher than the blank OD490 $\mathrm{nm}$.

Generally, when a foreign antigen invades host cells, the immune system works to produce antibodies by humoral immunity. Foreign antigens are phagocytosed by antigenpresenting cells (APCs) and presented to MHC class II molecules together with antigenderived peptide. The linear epitope-specific peptide on APCs activates helper T cells and initiates a series of events to induce humoral immunity [25-28]. By activating humoral immunity, some B lymphocytes are stored as memory B cells, triggering class-switching. Indeed, this common mechanism could be applied to the production of conformationspecific antibodies by presenting the stereospecific epitope to helper T cells. However, few reports have elucidated whether DNA immunization can elicit the class-switching of stereospecific antibodies from IgM to IgG.

Target antigens expressed in vivo by immunization using gene-coding nucleic acids such as DNA and mRNA must retain their original native three-dimensional structures, and so can be recognized by an immune system to sensitize B lymphocytes generating conformation-specific antibodies, probably in a similar manner as observed in natural infection by foreign pathogens. The intact structures of the target antigens would be of critical importance in effective infection and immunization.

\subsection{IgG and IgM Production of Stereospecific Monoclonal Antibodies by DNA Immunization and} Cell Immunization

A pivotal point for class-switching of stereospecific monoclonal antibodies seems to be the difference between Fusion III and Fusion IV. As shown in Table 1, they have almost the same total sensitization period, but different numbers of DNA immunizations: three in Fusion III and four in Fusion IV. The rate of IgM production decreased from $100 \%$ to $46.2 \%$, and the production of IgG was increased from $80.0 \%$ to $100 \%$ in Fusion IV, as compared to that in Fusion III. Moreover, while the $\triangle \mathrm{OD}$ values indicating the concentration of immunoglobulin IgG were less than 1.0 in Fusion III (Figure 3C), their production was frequently observed to be more than 1.0 in Fusion IV (Figure 3D). Among them, IgG-type conformation-specific monoclonal antibodies produced by hybridoma D6 in Fusion IV exhibited higher affinity toward intact huCRHR1 with a $\triangle \mathrm{OD}$ value of more than 0.7 by the Cell-ELISA method. Indeed, pre-selection of sensitized B lymphocytes by intact antigen through BCRs by the optimized SST technique featured preferential selection of the IgG isotype. Interestingly, IgM production by Cell-ELISA-positive hybridoma cells was almost 
completely absent in Fusion V (Figure 3E); however, affinity maturation of all stereospecific monoclonal antibodies was not necessarily observed in Fusion $\mathrm{V}$, since a few hybridoma cells were acquired in this trial. These results suggest that multiple DNA immunizations with four times and a sensitization period of three months or longer would be suitable for the selective generation of IgG-type stereospecific monoclonal antibodies by the optimized SST technique.

A
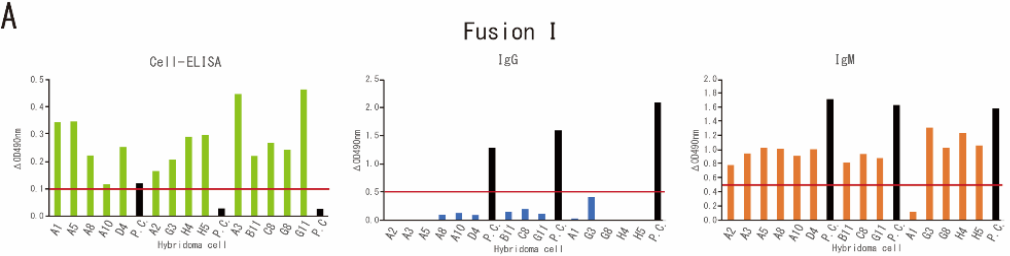

B
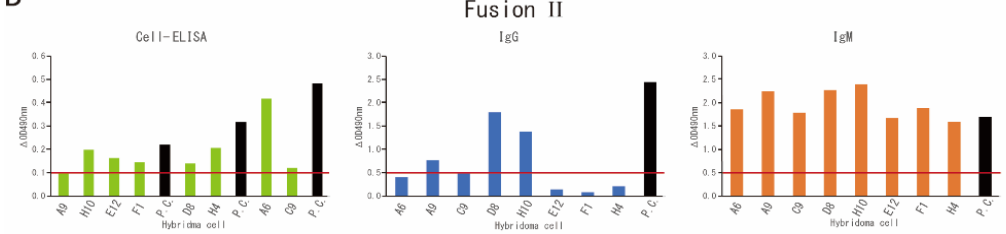

C

Fusion III
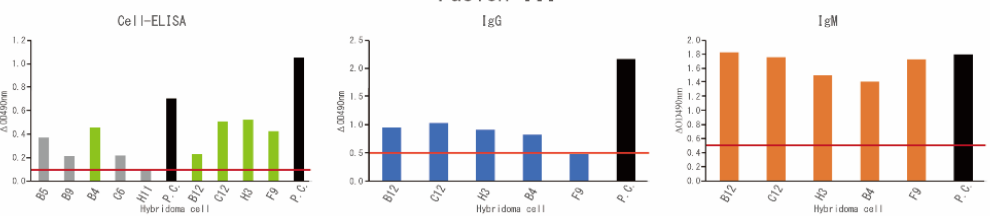

D

Fusion IV
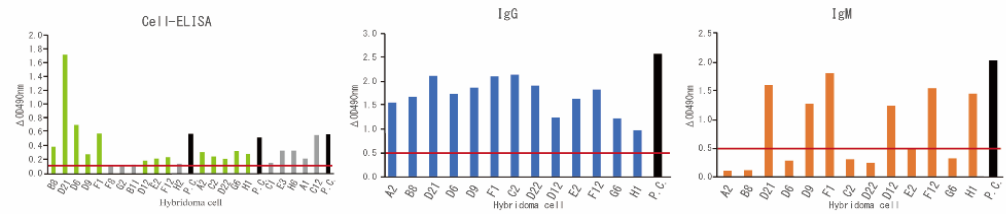

$\mathrm{E}$

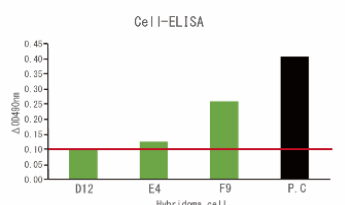

Fusion V
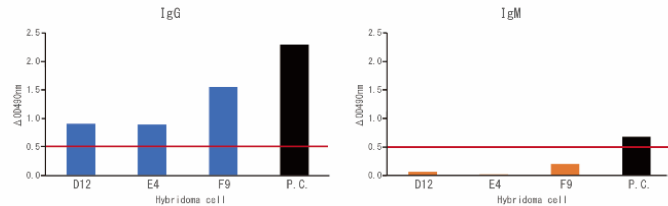

Figure 3. Determination of isotype and specific affinity of monoclonal antibodies generated by the optimized SST technique. Three mice per group were sensitized by DNA and cell immunization at one time. One of the sensitized mice was used for each experiment. (A-E) Five different immunization protocols (Fusions I to V) were used for sensitizing B lymphocytes. The specific affinity of monoclonal antibodies (left panel) in supernatant of hybridoma cells was evaluated by the Cell-ELISA method by means of huCRHR1-expressing $\mathrm{CHO}$ cells as an antigen. Monoclonal antibodies in hybridoma supernatant determined by both Cell-ELISA and ELISA methods are shown in green, whereas those measured by only the Cell-ELISA method are in gray in (C,D) (left panel). IgG (middle panel) and IgM (right panel) isotypes of monoclonal antibodies in hybridoma supernatant were quantified by the ELISA method as described in the Materials and Methods. Mouse serum diluted 1/100-(left panel), 1/200—(left panel) or 1/2000—fold (middle and right panels) obtained by DNA and cell immunization in Fusions I to $\mathrm{V}$ was used as a primary antibody for the positive control (P.C.), where 1/100 — and 1/200 — fold diluted mouse sera were used in Fusions I to III and Fusions IV and V, respectively. $\triangle \mathrm{OD}$ values at $490 \mathrm{~nm}$ for $(\mathbf{A}-\mathbf{E})$ are shown in Table S1.

In the present study, we found that the class-switching of conformation-specific antibodies from IgM to IgG was promoted by controlling the number of DNA immuniza- 
tions and the sensitization period. This class-switching could be triggered by memory B lymphocytes that had been pre-sensitized by APCs and memory T lymphocytes. This class-switching must provide advantages for conformation-specific antibodies by acquiring higher affinity for the target native antigen by rearranging the genes of complementaritydetermining regions (CDRs) in antibodies under somatic hypermutation [13]. The optimized SST technique should make it possible to preferentially select B lymphocytes producing IgG-type conformation-specific monoclonal antibodies through BCRs by the native antigen on myeloma cells. In particular, cell-based immunization could allow the swift class-switching of antibodies to IgG, since the intact antigens on CHO cells may directly stimulate an immune response without expressing them from the DNA gene.

In conclusion, we addressed the question of how intact antigens are processed in APCs and their original native structures can be retained when they are presented on the surface of APCs together with MHC class II molecules. While this question is still un-answered, the present study implies that the presentation of stereospecific epitopes ex-pressed in vivo from the recombinant gene to helper $\mathrm{T}$ cells may be able to cause the ap-propriate immune response followed by switching of the isotype of conformation-specific monoclonal antibodies from IgM to IgG, resulting in efficient acquisition of hybridoma cells efficiently secreting IgG monoclonal antibodies. Since the positive and direct selection of the sensitized target $\mathrm{B}$ cells through specific interaction between the BCRs and in-tact antigens is used in the optimized SST technique, efficient immunization by expressing native antigen proteins in vivo using the coding DNAs can apparently promote the production of hybridoma cells secreting the target stereospecific antibodies, though the correlation between class-switching in sensitized B cells and the acquisition rate of the de-sired hybridoma cells remains to be further investigated.

Supplementary Materials: The following data are available online at https://www.mdpi.com/ article/10.3390/immuno1040031/s1, Table S1: $\triangle$ OD values at 490nm for Figure 3A-E.

Author Contributions: Conceptualization, Y.I., K.T. and M.T.; methodology, Y.I.; validation, Y.I., K.T. and M.T.; formal analysis, Y.I., K.T. and M.T.; investigation, Y.I.; data curation, Y.I.; writing-original draft preparation, Y.I.; writing—review and editing, Y.I., K.T. and M.T.; visualization, Y.I.; supervision, M.T.; project administration, M.T.; funding acquisition, M.T. All authors have read and agreed to the published version of the manuscript.

Funding: This research was supported in part by JSPS KAKENHI, grant number JP24360339, JP25630376 and JP17H03468) to M.T.

Institutional Review Board Statement: All experiments were performed according to the guidelines of the Mie University for the care and treatment of experimental animals.

Informed Consent Statement: Not applicable.

Data Availability Statement: The date presented in this study are available from the corresponding author upon request.

Conflicts of Interest: The authors have no other relevant affiliations or financial involvement with any organization or entity with a financial interest in or financial conflict with the subject matter or materials discussed in the manuscript other than those disclosed.

\section{References}

1. Liu, M.A. A comparison of plasmid DNA and mRNA as vaccine technologies. Vaccines 2019, 7, 37. [CrossRef] [PubMed]

2. Li, L.; Petrovsky, N. Molecular mechanisms for enhanced DNA vaccine immunogenicity. Expert Rev. Vaccines 2016, 15, 313-329. [CrossRef] [PubMed]

3. Liu, M.A. DNA vaccines: An historical perspective and view to the future. Immunol. Rev. 2011, 239, 62-84. [CrossRef] [PubMed]

4. Pardi, N.; Hogan, M.J.; Porter, F.W.; Weissman, D. mRNA vaccines-A new era in vaccinology. Nat. Rev. Drug Discov. 2018, 17, 261-279. [CrossRef] [PubMed]

5. Kaplon, H.; Reichert, J.M. Antibodies to watch in 2019. MAbs 2019, 11, 219-238. [CrossRef] [PubMed]

6. Yu, J.; Song, Y.; Tian, W. How to select IgG subclasses in developing anti-tumor therapeutic antibodies. J. Hematol. Oncol. 2020, 13, 45. [CrossRef]

7. Thomas, A.; Teicher, B.A.; Hassan, R. Antibody-drug conjugates for cancer therapy. Lancet Oncol. 2016, 17, e254-e262. [CrossRef] 
8. Tsumoto, K.; Isozaki, Y.; Tomita, M. Production of monoclonal antibodies. In Culture of Animal Cells: A Manual of Basic Technique and Specialized Applications, 7th ed.; Freshney, R.I., Ed.; Wiley-Blackwell: Hoboken, NJ, USA, 2016; pp. $544-545$.

9. Yamasaki, Y.; Miyamae, C.; Isozaki, Y.; Ichikawa, K.; Kaneko, Y.; Oda, Y.; Murayama, T.; Sakurai, T.; Tamai, K.; Tsumoto, K.; et al. Optimization of stereospecific targeting technique for selective production of monoclonal antibodies against native ephrin type-A receptor 2. J. Immunol. Methods 2020, 484-485, 112813. [CrossRef]

10. Isozaki, Y.; Tsumoto, K.; Tomita, M. Conformation-specific monoclonal antibodies recognizing the native structure of $\mathrm{G}$ proteincoupled receptor (GPCR). Int. Immunopharmacol. 2021, 98, 107872. [CrossRef]

11. Stavnezer, J.; Schrader, C.E. IgH chain class switch recombination: Mechanism and regulation. J. Immunol. 2014, 193, 5370-5378. [CrossRef]

12. Yewdell, W.T.; Chaudhuri, J. A transcriptional serenAID: The role of noncoding RNAs in class switch recombination. Int. Immunol. 2017, 29, 183-196. [CrossRef]

13. Muramatsu, M.; Kinoshita, K.; Fagarasan, S.; Yamada, S.; Shinkai, Y.; Honjo, T. Class switch recombination and hypermutation require activation-induced cytidine deaminase (AID), a potential RNA editing enzyme. Cell 2000, 102, 553-563. [CrossRef]

14. Stavnezer, J.; Guikema, J.E.; Schrader, C.E. Mechanism and regulation of class switch recombination. Annu. Rev. Immunol. 2008, 26, 261-292. [CrossRef] [PubMed]

15. Pioszak, A.A.; Parker, N.R.; Suino-Powell, K.; Xu, H.E. Molecular recognition of corticotropin-releasing factor by its G-proteincoupled receptor CRFR1. J. Biol. Chem. 2008, 283, 32900-32912. [CrossRef] [PubMed]

16. Stocker, J.W.; Forster, H.K.; Miggiano, V.; Stahli, C.; Staehelin, T. Generation of two new myeloma cell lines 'PAI' and 'PAI-O' for hybridoma production. Res. Discolsure 1982, 21, 7155-7157.

17. Lo, M.M.S.; Tsong, T.Y.; Conrad, M.K.; Strittmatter, S.M.; Hester, L.D.; Snyder, S.H. Monoclonal antibody production by receptor-mediated electrically induced cell fusion. Nature 1984, 310, 792-794. [CrossRef]

18. Costagliola, S.; Rodien, P.; Many, M.C.; Ludgate, M.; Vassart, G. Genetic immunization against the human thyrotropin receptor causes thyroiditis and allows production of monoclonal antibodies recognizing the native receptor. J. Immunol. 1998, 160, $1458-1465$.

19. Costagliola, S.; Franssen, J.D.; Bonomi, M.; Urizar, E.; Willnich, M.; Bergmann, A.; Vassart, G. Generation of a mouse monoclonal TSH receptor antibody with stimulating activity. Biochem. Biophys. Res. Commun. 2002, 299, 891-896. [CrossRef]

20. Takatsuka, S.; Sekiguchi, A.; Tokunaga, M.; Fujimoto, A.; Chiba, J. Generation of a panel of monoclonal antibodies against atypical chemokine receptor CCX-CKR by DNA immunization. J. Pharmacol. Toxicol. Methods 2011, 63, 250-257. [CrossRef]

21. Koch-Nolte, F.; Glowacki, G.; Bannas, P.; Braasch, F.; Dubberke, G.; Ortolan, E.; Funaro, A.; Malavasi, F.; Haag, F. Use of genetic immunization to raise antibodies recognizing toxin-related cell surface ADP-ribosyltransferases in native conformation. Cell Immunol. 2005, 236, 66-71. [CrossRef]

22. Øynebråten, I.; Løvås, T.O.; Thompson, K.; Bogen, B. Generation of antibody-producing hybridomas following one single immunization with a targeted DNA vaccine. Scand. J. Immunol. 2012, 75, 379-388. [CrossRef] [PubMed]

23. Tan, G.S.; Krammer, F.; Eggink, D.; Kongchanagul, A.; Moran, T.M.; Palese, P. A pan-H1 anti-hemagglutinin monoclonal antibody with potent broad-spectrum efficacy in vivo. J. Virol. 2012, 86, 6179-6188. [CrossRef]

24. Nagata, S.; Salvatore, G.; Pastan, I. DNA immunization followed by a single boost with cells: A protein-free immunization protocol for production of monoclonal antibodies against the native form of membrane proteins. J. Immunol. Methods 2003, 280, 59-72. [CrossRef]

25. Schmidlin, H.; Diehl, S.A.; Blom, B. New insights into the regulation of human B-cell differentiation. Trends Immunol. 2009, 30, 277-285. [CrossRef] [PubMed]

26. Tangye, S.G.; Tarlinton, D.M. Memory B cells: Effectors of long-lived immune responses. Eur. J. Immunol. 2009, 39, 2065-2075. [CrossRef]

27. Nicholson, L.B. The immune system. Essays Biochem. 2016, 60, 275-301. [CrossRef] [PubMed]

28. Yatim, K.M.; Lakkis, F.G. A brief journey through the immune system. Clin. J. Am. Soc. Nephrol. 2015, 10, 1274-1281. [CrossRef] [PubMed] 